\title{
Curricula and curricular analysis: Some pointers for a debate
}

\author{
Philippe Jonnaert • Geneviève Therriault
}

Published online: 7 December 2013

(C) UNESCO IBE 2013

\begin{abstract}
This introduction to our guest-edited issue provides a framework for reflecting on curricula, based on the four still fundamental questions raised by Tyler (Basic principles of curriculum and instruction. University of Chicago Press, Chicago, 1949) about effective ways to organize educational experiences that can meet the school's educational purpose. The authors begin by decoding the Franco-European and Anglo-Saxon/North American approaches to the concept of curriculum, and seek points where the two are complementary. Using Tyler's four questions, they then clarify the concept in a conceptual outline, organize it into a rational model, and seek a reference framework that can offer pointers for a debate on curriculum. They then show that, because a curriculum necessarily originates in a specific society, some of that society's irrationality affects the nature of the curriculum. Thus, any curriculum experiences a tension between the rationality of the models that define it in theoretical terms and the irrationality of its surrounding societywhich has the power to regulate it. Therefore, tools for curriculum analysis must consider all these dimensions, contradictions, and tensions to achieve a truly systemic perspective. While a system model is important for evaluation, it is also important to understand the less rational aspects and to place them in dialogue with their models. In this respect, providing pointers for the debate on curriculum remains a perilous exercise. Finally, the authors reflect on a systemic and holistic approach to the curriculum, and suggest pointers for contemporary reflection on curriculum.
\end{abstract}

\footnotetext{
P. Jonnaert $(\bowtie)$

Université du Québec à Montréal, Succursale Centre-ville, C.P. 8888, Montreal, QC H3C 3P8, Canada e-mail: jonnaertp@gmail.com

G. Therriault

Université du Québec à Rimouski, 300, Allée des Ursulines, C.P. 3300, Rimouski, QC G5L 3A1,

Canada

e-mail: genevieve_therriault@uqar.ca
} 
Keywords Curriculum - Education programmes - Curriculum levels · Model · Hierarchical inclusion · Logical relationship · Curriculum analysis · Curriculum reform

In a valuable reference work, Cecilia Braslavsky (2001) undertook a review of the curriculum reforms occurring in many education systems throughout the world since the end of the 1980s. Among her observations, she demonstrated how the very concept of curriculum had evolved, and pointed out the need to refocus it. A decade later, this movement has been extended and the concept of the curriculum is now at the heart of discussions on education. For example, a recent thematic issue of the Revue International de l'Éducation de Sèvres (edited by R.-F. Gauthier 2011) is called Le curriculum dans les politiques éducatives (The curriculum in education policy).

This introductory article forms part of this contemporary effervescence of reflection on curricula. Without necessarily offering definitive responses to the questions Braslavsky raised, we place the curriculum in a dual dynamic, one Anglo-Saxon and North American, and the other Franco-European. Taking a systemic and holistic view of the concept of the curriculum, we propose to open it up, rather than locking it into a rigid model, even though it is necessary to develop a model for the concept. Avoiding the use of the term reform, which tends to denote an upheaval, we prefer to speak of the adaptation of curricula. We do so from a constructivist and Piagetian perspective, in the sense of including the attainments of curricula that are being implemented in relation to trends in societal education and training needs. In this respect, the curriculum becomes a tool for regulating and adapting education systems to social trends. In view of its specific location, as a small Frenchspeaking enclave in North America, the UNESCO Chair in Curriculum Development (UCCD) is at the crossroads of the two current curricular movements. Without contrasting them, we seek complementarities. While the terms curriculum and education programmes are often confused with each other in Franco-European countries, a clear distinction is made between them in the Anglo-Saxon/North American world.

"Education programme" is the standard usage in the International Standard Classification of Education (ISCED) (UIS 2012) in the version amended by the UNESCO General Conference in November of 2011 and described by Jonnaert and Ettayebi (2007, pp. 24-25): "Education programmes provide useful information for the organization of teaching, learning and evaluation activities. It is through education programmes that a curriculum becomes operational in the classroom. There are generally a number of $e d u$ cation programmes in a curriculum, but there should in principle only be one curriculum for an education system". Throughout this article, we use the term education programme strictly within this meaning; it cannot be superimposed upon that of curriculum. FrancoEuropean education systems regularly use the term "programme of studies" instead of "education programme". (Please note that throughout this article, all translations from French are ours).

We base our work on the questions Tyler (1949) laid out, using them to analyse the concept of the curriculum in each of these two worlds. With a view to broadening these pointers, we clarify the concept of the curriculum and articulate its components in what we call a conceptual outline (Jonnaert, Ettayebi, and Defise 2009). Drawing on that, we demonstrate that it would be seeking utopia to try and develop a rational model for the concept of the curriculum. This is because, when a curriculum is placed in its social environment, it also bears the weight of the irrational nature of any society. We then 
position each of the articles in this issue in relation to the pointers we have proposed for reflection on curricular issues.

In the first section we briefly describe the Anglo-Saxon and Franco-European curriculum movements in light of Tyler's questions. In the next section we clarify the concept of curriculum by organizing its various dimensions into a conceptual outline, before distributing them over the time period of curriculum development. We then demonstrate the relative nature of this over-rational logic by situating the curriculum in the irrationality of societies. We conclude by placing curricular reflection into perspective.

\section{What status should a curriculum have?}

In this first section, we briefly outline the concept of curriculum as it has developed under two different approaches, one Anglo-Saxon and North American, and the other FrancoEuropean. As we review these two approaches we draw on the four questions Tyler (1949) laid out as a structure for curricular reflection:

1. What educational purposes should the school seek to attain?

2. What educational experiences can be provided that are likely to attain these purposes?

3. How can these educational experiences be effectively organized?

4. How can we determine whether the purposes are being attained?

But what curriculum are we talking about? The concept of the curriculum has become a traditional subject for studies and research in departments of curriculum sociology in Anglo-Saxon and North American universities. But was that always the case? Pinar (2009, p. 267) recalls that Tyler was the first theorist to fully conceptualize the notion of the curriculum in a reference work: "The culminating event of the first paradigmatic moment was the appearance, in 1949, of what has been termed the bible of curriculum development: Ralph W. Tyler's Basic principles of curriculum and instruction". Reflection on curriculum development therefore goes back more than half a century in North America, and indeed still further back if one includes the pioneering thinkers, such as Bobbitt (1918) and Dewey (1899, 1902). Indeed, Dewey (1902), who brought the academic and public universes closer through the term "curriculum", reveals how broad a scope curriculum can have. He believed that, through academic and public discussions, curriculum involves both the school and society, and students and their parents and teachers. It involves their social, cultural, and economic environment, as well as their administrative and political context, etc. The complexity of curriculum was evident from the outset; it meant that the approach, admittedly difficult, was already global and undoubtedly somewhat holistic. This complexity probably explains why it was so slow to emerge. After a period in which interest in curriculum studies fell off (Wraga and Hlebowitsh 2003), and the field even lost influence (Kliebard 1995), today the field is experiencing a veritable renaissance. It is moving towards becoming an autonomous disciplinary field developed in independent departments and faculties in countries of the Anglo-Saxon tradition.

This disciplinary field, so fertile in the Anglo-Saxon and North American countries, seems, in contrast, to be somewhat foreign to education and other university faculties and departments in the Franco-European area. However, it has recently taken its place at the heart of certain French-language educational studies, including those by Audigier, TutiauxGuillon, and Haeberli (2008); Depover and Noël (2005); D’Hainaut (1981, 1988); Malet (2010); and Perrenoud (1984) or in the sociology of curriculum. Although broadly inspired 
by the British approach to the curriculum (Forquin 1984, 1989, 2008), the concept of the curriculum is still ill-defined in the field of Franco-European education. The two movements therefore seem to be drawing apart somewhat. It is worthwhile considering each one separately.

The Anglo-Saxon and North American curriculum movement offers a vision of the curriculum in an education system which goes beyond that of the education programme as defined by the ISCED. Curriculum studies have been developing for over a century, beginning with Dewey $(1899,1902,1938)$ and Bobbitt $(1918,1924)$ and up to the most modern research and publications such as Connelly, He, and Fillion (2008); Jackson (1992); Keeves (1992); Kridel (2009); and Pinar (2003, 2004, 2009). According to these Anglo-Saxon and North American researchers and theoreticians, a curriculum is systemic and is considered to be a broad and inclusive pedagogical action plan. A curriculum admittedly includes a number of education programmes in different learning fields, but does not replace or reduce them. These education programmes provide partial responses to Tyler's second question: what educational experiences can be provided to learners with a view to attaining pre-defined purposes? However, a curriculum cannot be reduced to this single dimension and respond solely to this question. A curriculum necessarily has to be positioned upstream from education programmes and has to determine their purposes and orientations. In so doing, it provides responses to Tyler's first question concerning the purposes of education. Clearly, a curriculum is not confined to the orientation of education programmes alone. Among other functions, it proposes guidelines for teaching and learning activities, it provides indications for teaching materials and textbooks, it determines the pedagogical and linguistic system, and it sets out the main lines of teacher training. Thus, through a series of openings, a curriculum suggests responses to Tyler's third question: what educational strategies should be implemented to achieve these purposes and organize these educational experiences? Finally, a curriculum provides a series of instructions for evaluating the attainments of both students and teachers, and even for evaluating the curriculum as a whole. Thus, it responds to Tyler's fourth question concerning evaluation.

With this vision, the curriculum extends broadly beyond technocratic issues, such as codifying knowledge, determining objectives, and formalizing competencies in education programmes, which are merely the means for implementing curricular orientations. This Anglo-Saxon and North American curriculum movement is also concerned with the functionality of learning. As seen from this perspective, Dewey's (1938) references to the life experiences of learners and to pragmatism are often perceptible. A curriculum forms part of a society at a specific moment in its history, and thus is impregnated with cultural, social, and historical dimensions. As a local product, a curriculum that forms part of this movement is therefore difficult to export. Contextualized in a clearly circumscribed environment, it nevertheless remains open to the world through the international standards with which it endeavours to ensure the consistency of its education programmes. It is from this perspective that the curriculum becomes one of the essential tools enabling an education system to adapt to a society's needs for education and training. In this sense, rather than speaking of reforms, specialists in curriculum issues refer in particular to the curriculum in development (Jonnaert and Ettayebi 2007; Lafortune, Ettayebi, and Jonnaert 2007) and address curriculum adaptation. The curriculum then becomes an actual tool for regulating education systems, admittedly on condition that it responds to Tyler's (1949) four fundamental questions, which are still relevant but now somewhat incomplete. Thus we need to add other questions in order to address a global and complex idea of curriculum, with a view to developing a truly holistic reflection on the curriculum of an education system. 
The contemporary Franco-European curriculum movement provides a relatively unstable image of the concept of the curriculum, even when discussed in French. A review of the French-language education literature shows that the concepts of education programme and curriculum appear to be used interchangeably. For example, Reuter, CohenAzria, Daunay, Delcambre, and Lahanier-Reuter (2007, p. 185) write that

... pedagogical planning means the process of planning in time the content of teaching in a discipline. In its broadest sense, pedagogical programming is consubstantial with the education system and is one of the important characteristics of school structure, envisaging as it does the progressive discovery of teaching content in the school cycle: the curriculum can be defined as all disciplinary programmes: ... the curriculum designates the programming of teaching content throughout schooling.

This definition of the curriculum reflects an aspect of Franco-European curricular thinking which, still today, considers a curriculum to be a series of education programmes developed on a disciplinary basis. In such cases, the curriculum determines "the finalized content of teaching, subject to objectives transmitted methodically" (Danvers 1992, p. 68). In Franco-European research works, the concepts of curriculum and education programme are superimposed. They deal principally with knowledge, subjects, and school disciplines, with the content of learning, and with their epistemological basis, programming, structure, and organization.

From this perspective, the organization, structuring, codifying, and hierarchy of knowledge appear to be the focus of a curriculum. Even if the concept of curriculum is mentioned, it refers essentially to the content of teaching:

In recent French-language sociological works, a distinction is sometimes drawn between the 'intended' or 'formal curriculum', which gathers together everything that is intended to be taught and learnt at a specific level, and the 'achieved curriculum', which covers what is actually provided by teachers to students in the context of pedagogical activities. (Forquin 2008, p. 99, emphasis added)

Perrenoud (1984) introduced this distinction that Forquin describes, between the "formal" or "official curriculum" and the "real curriculum", but in the same work, he also uses the term "programme" to refer to the intended curriculum.

Programmes, which we refer to here as "education programmes", following ISCED, essentially cover the content of teaching and learning; it is at the level of terminology that they are confused with the concept of curriculum in the Franco-European approach. In line with Verret (1975), experts in the pedagogy of sciences and mathematics (Chevallard 1985; Chevallard and Joshua 1982) analyse the mechanisms for reconstructing knowledge on the basis of "theoretical knowledge" or "social practices of reference" (Martinand 1986, 2001), to the point when they were codified in education programmes and adapted into teaching and learning activities; their research essentially, if not exclusively, addresses school disciplines and the progressive transformation of knowledge. The concepts of obstacle-objective and social practices of reference introduced by Martinand (1986, 2001), but described in earlier works by D'Hainaut (1970, 1971), are very important. These concepts are powerful, as they destabilize a monolithic vision of knowledge. D'Hainaut (1971) also introduced the notion of cognitive-pre-attainments (PAC) in formulating items for a programmed course with a view to presenting to science students the conceptions he had observed among other students addressing the same concept. Others worked on the PAC, using other pedagogical terms for sciences and mathematics (representation, 
conception, pre-conception, pre-existing, etc.), particularly during the 1980s. By introducing the PAC, D'Hainaut destabilized the strictly codified knowledge in education programmes and, finally, to some extent, humanized the knowledge that was generally presented to students for its own sake.

However, these concepts have had only a minimal impact on contemporary and FrancoEuropean curriculum studies relating to the way that school knowledge is selected and codified in education programmes. In this respect, this movement essentially addresses Tyler's second question concerning educational experiences, and more specifically the codified and prescribed curricular content of education programmes for these experiences. In practice, the logic of each discipline guides the content and organization of education programmes in this movement. From this viewpoint, since the Franco-European logic can also see an education programme as a curriculum, the same education system could have as many curricula as it has school disciplines, and also as many forms of organization for its education programmes, as these same disciplines determine their organization.

Thus we see a problem of logic when curriculum and education programmes are superimposed. In practice, in this movement, the generic envelope, the curriculum, which normally includes the specific envelopes - the education programmes-is confused with the specific envelope, thereby overturning a relationship that is normally one of hierarchical inclusion: the curriculum includes the education programmes, which it guides, and not the other way around. This relationship, when it is reversed, creates difficulties, like those described by the authors assembled by Tehio (2010); Gauthier, in this issue, also addresses these issues. While a curriculum is developed by progressively addressing each of Tyler's (1949) four questions, in the Franco-European movement, Tyler's second question, relating to educational experiences, and therefore their content, appears to prevail over the other three questions. Indeed, it is dominant. Even when authors defend themselves against this criticism, school knowledge and competencies remain central to their curricular thought:

...we have retained the term curriculum in preference to those of programme or study plan, with a view to situating our reflection in a broad perspective concerning school knowledge, ranging from its definition to its implementation and evaluation, and we do not confine our research to the sole official texts strictly related to a specific discipline or school subject. (Audigier et al. 2008, p. 17)

From this Franco-European viewpoint, the concept of curriculum, when superimposed on that of education programme, is reduced to the issue of how to organize learning content. This type of curriculum is focused on the transmission and construction of content, whether defined in terms of knowledge, competencies, or objectives in the education programmes. In the following section we seek areas where the two movements might be complementary.

\section{Potential complementarities}

Undoubtedly, Tyler's (1949) four questions have already led to the spilling of much ink, but they remain the fundamental basis of curriculum development. The two approaches we have described do not address the concept of the curriculum from the same logic. While Tyler's questions offer a good framework for the Anglo-Saxon/North American curriculum movement, particularly in relation to curriculum development, they are not adapted to the Franco-European approaches. The Anglo-Saxon/North American movement places the curriculum upstream of the education programmes that it orients and encompasses. It therefore starts out with research on educational needs and purposes, 
thereby responding to Tyler's first question. The Franco-European movement superimposes two concepts, using either one to refer to the other. It thus shuffles the cards and, most frequently, uses the concepts of the curriculum and the education programme synonymously. Thus it undermines Tyler's questions and cannot provide a framework for this approach, which is nevertheless in full effervescence.

Rather than contrasting these two perspectives, we believe we should place them side by side and understand the nature of the relationship between them. Neither of the two approaches necessarily excludes the other. The programmatic dimension of learning content in French-language European curricula completes the global, humanistic, and pragmatic vision of the Anglo-Saxon curriculum and vice versa. Perhaps, if we recall the nature of the relationship that exists between 'curriculum' and 'education programme', the two concepts can find their appropriate places and the complementarity between the two approaches can be stabilized. But is that sufficient? Could Tyler's questions then be applied to both approaches? Moreover, are these questions sufficient in themselves? We now consider the relationship that may exist between the two terms, before returning to Tyler's questions.

The relationship between 'curriculum' and 'education programme'

As already noted, a relationship of hierarchical inclusion defines the links between a curriculum and education programmes. A curriculum orients the educational action that occurs in an education system. Education programmes define and codify the content of learning and training in accordance with the orientations of the curriculum. Education programmes are only the means to put into practice the orientations set out in the curriculum. They specify the content of learning experiences and educational action, making them completely coherent with the prescriptions of the curriculum and its orientations. In this case, the curriculum necessarily includes the education programmes in a strict hierarchical relationship. This relationship cannot be reversed. Nor can we eliminate it by superimposing the two concepts using synonymous terms. Once the relationship between curriculum and education programme is defined, it is possible to analyse how they are complementary. This is also the relationship that brings the two movements-the AngloSaxon/North American and the Franco-European-closer. Indeed, it repositions the two concepts - curriculum and education programmes - in a clearly established relationship, but also situates them within the pointers laid out by Tyler (1949). It is undoubtedly necessary to reposition these pointers, and even to specify them in relation to dimensions other than just the curriculum in development. Finally, by re-specifying these pointers, it will be possible to address the Franco-European movement much more completely. Therefore we now examine these questions with a view to broadening them.

\section{Broadening Tyler's questions}

Tyler's four questions remain interesting and still provide a basis for any reflection on curriculum development: the process of developing a curriculum. Beyond that, they are no longer sufficient. Reflection on curricula takes on very different forms depending on the purposes of the curricular activities being pursued (Luke 2008).

For example, such curricular activity may occur at six different levels. 
- At a theoretical or empirical level, theoretical or empirical work on curriculum is taken as the subject of study.

- At the level of curriculum development (the stages of writing a curriculum and the categories of action necessary to do so, the course of action to develop it, etc.), the curriculum is considered as a process.

- At the level of the overall results of this process (texts setting out the purposes, an orientation framework for the curriculum, education programmes, an evaluation policy, etc.), the curriculum is analysed as a product.

- At the level of curriculum implementation (the progressive processes of introducing and adjusting it, etc.) it is taken as a reference framework for introducing change.

- At the level of adjusting the curriculum itself (analysing, evaluating, and adapting the curriculum), it becomes the subject of adaptation.

- At the level of regulating an education system, the curriculum is considered the means for regulating the whole education system.

Accordingly, a curriculum successively, and sometimes simultaneously, takes on various forms, as a subject of study, a process, a product of this process, a reference framework, a subject of adaptation, and even a means of regulation. These various forms may all apply to the same curriculum, which progressively advances towards learning outcomes at school, and even beyond. It is very important to consider these different forms of a curriculum at the various stages of its evolution to avoid confusion, such as the oftenobserved superimposing of curriculum and education programmes. However, the fact that the same curriculum can take on these various forms during its development also shows that unless a curriculum is addressed fully and completely, it can become a kaleidoscope, sending out 1001 images, too much for any observer to take in.

Therefore, a curriculum is necessarily embedded in the complexity of its own historical development. Accordingly, D'Hainaut (1981) offers a systemic and global vision, placing the curriculum back in its context and environment and, accordingly, in line with Dewey (1902), positioning it in a holistic perspective. This is why, before we begin to address the issue of broadening Tyler's questions, we must first develop a model for the curriculum, going beyond Tyler's propositions: "establishing a model for the enterprise involves developing a model for a series of actions that are intelligible in relation to their purposes in an environment within which it functions and is transformed" (Le Moigne 1987, p. 512). But, can a curriculum really be subject to such a process for developing a model, given its great complexity? Moreover, are the categories of action involved in its development all intelligible?

At first glance the concept may seem to be too broad-a concept too inclusive to rule accounts in and out as being either curricular or not and therefore unhelpful to curricular scholarship. But the opposite is the case. The curriculum, in this view, is a way to entwine the disparate and fragmented lines that make up the modern educational world of scholarship. Curriculum is a way of integrating disparate lines of inquiry around the broad idea of experience in the relationships among teachers, students, subject matter, and milieu. Curriculum ... is never easy because curriculum

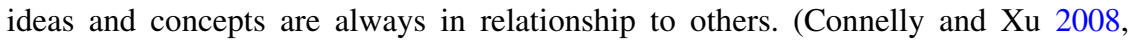
p. 519)

Moving beyond this complexity, in the next section we offer a conceptual clarification of the curriculum with a view to developing a model and then revisiting Tyler's questions. 


\section{A proposal for conceptual clarification}

Here we briefly describe a concept of the curriculum contained in a conceptual outline developed and validated by members of our research team at the UNESCO Chair in Curriculum Development (UCCD) (Jonnaert et al. 2009). Based on our analysis of the concept of curriculum and its components, we offer the following definition:

... a curriculum is a system made up of a series of educational components. Articulated among themselves, these components permit the orientation and operationalization of an education system through pedagogical and administrative action plans. It is anchored in the historical, social, linguistic, political, religious, geographical and cultural characteristics of a country, region or locality. (Jonnaert et al. 2009, p. 57)

The conceptual outline provided in Figure 1 illustrates the complexity of the curriculum in an education system. A curriculum clarifies the system's purposes and provides the basis for putting them into practice through coherent pedagogical and administrative action plans, while education programmes are the means used to do so. A curriculum necessarily operates on a systemic dimension and is endowed with local, national, or regional characteristics. As a curriculum is embedded in a systemic dimension, and consequently in complexity, multiplying curricula within the same educational system raises the risk of incoherence. This risk is particularly high in cases where the curriculum and the education programmes are superimposed, and even more so when the education programmes replace the curriculum, and we see as many curricula as there are education programmes that provide training in a system.

This conceptual outline traces the relationships between all the components of the system that is a curriculum. It is the outcome of the process of developing a model for this concept, one that allows a curriculum to be analysed (Laveault 2007). The outline has been validated at several levels within the research programme undertaken by the first author at UCCD. A validated version was published in Jonnaert et al. (2009), although it has been developed further; that article contains explanations of Figure 1 and Table 1. The process of developing a model is necessary, but not sufficient, as the curriculum still needs to be placed in the various stages of its development in an education system, starting with defining the orientations and moving right through to the learning that students achieve.

The model is not rigid. In fact, it is quite dynamic. It covers the various curricular levels (D’Hainaut 1981, 1988; Jonnaert 2011a; Keeves 1992; Perrenoud 1984) and regularly changes form. The official texts prepared by ministries appear between the lines in the various documents used by teachers and take on a very specific form during teaching/ learning activities in the classroom, often remote from the curriculum prescribed in official texts. The elements of the conceptual outline of a curriculum are therefore translated in various ways depending on the time and the persons concerned. Table 1 illustrates the dynamism of a curriculum. However, the outline offers a universal vision of the concept of the curriculum, and it is still necessary to indicate the format of the curriculum that is being analysed and the stage of curriculum development. And, it is crucial to repeat the analysis as the curriculum progresses through its various stages. This outline completes the pointers laid out by Tyler (1949).

The three basic frameworks at the heart of the conceptual outline (those for orientation, operationalization, and adjustment) provide the basis for situating a curriculum by crossreferencing it with the six forms, listed earlier, that a curriculum can take during implementation: subject, process, product, reference framework, subject of adaption, and means 


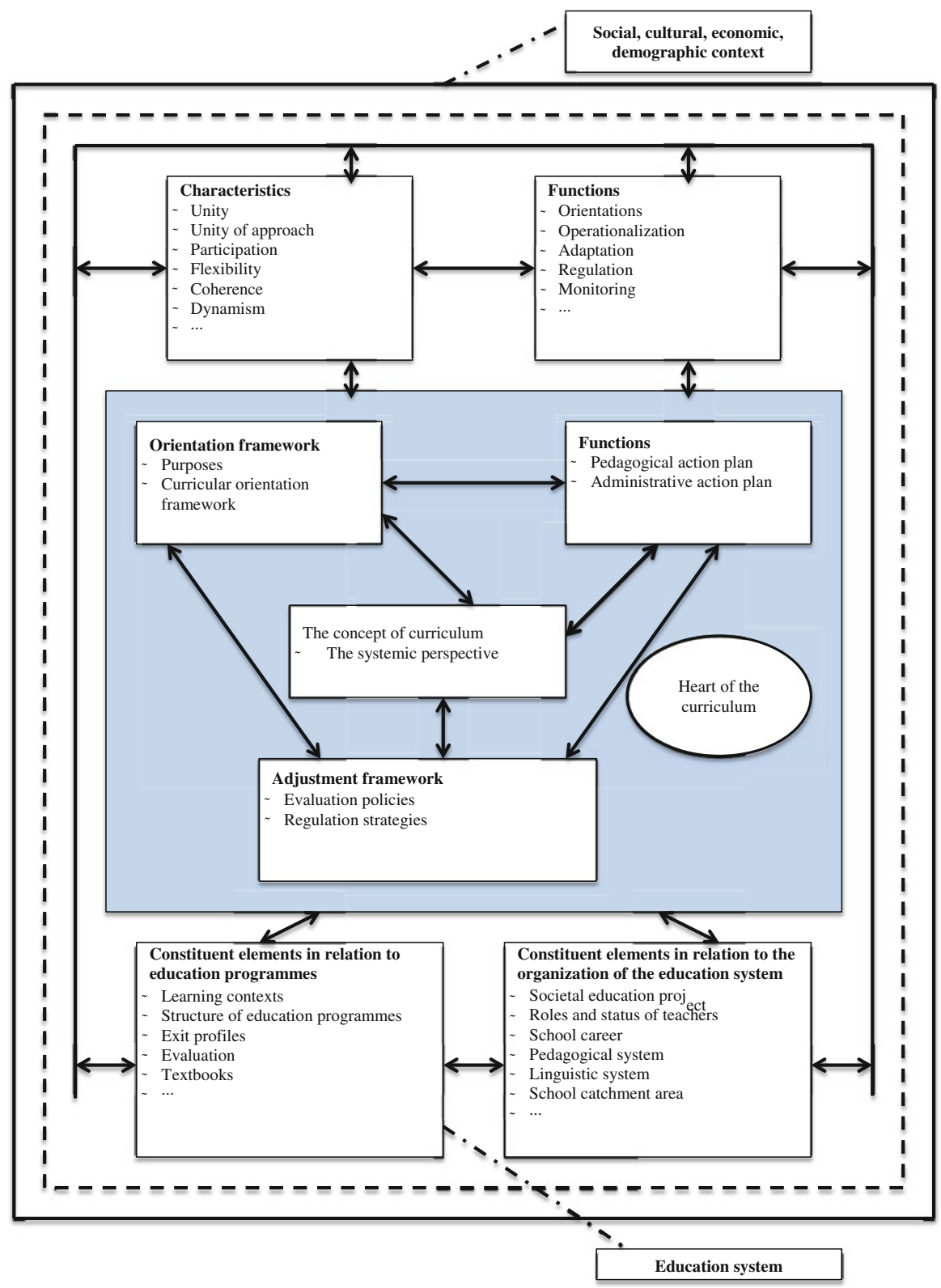

Fig. 1 General conceptual outline of the curriculum Source: Adapted from Jonnaert et al. (2009), p. 58

of regulation. Each of the resulting boxes can then be the subject of analysis, as we apply some or all of Tyler's four questions. With this broader application, these questions take on a whole new dimension and provide the basis for capturing a curriculum as it progresses, passing through the various forms we listed above. While the conceptual outline addresses the concept of the curriculum in a very general way, the form of the curriculum, when 


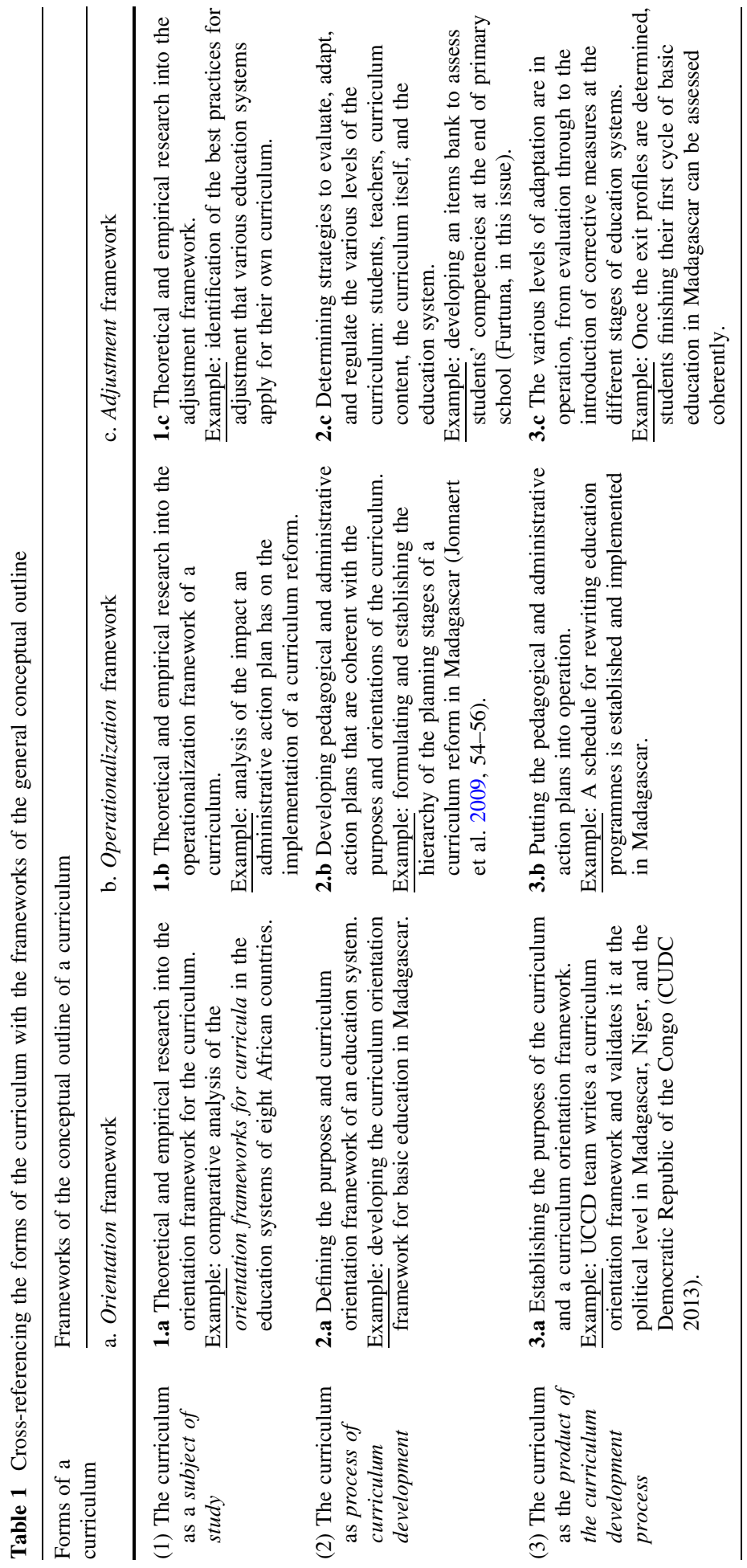




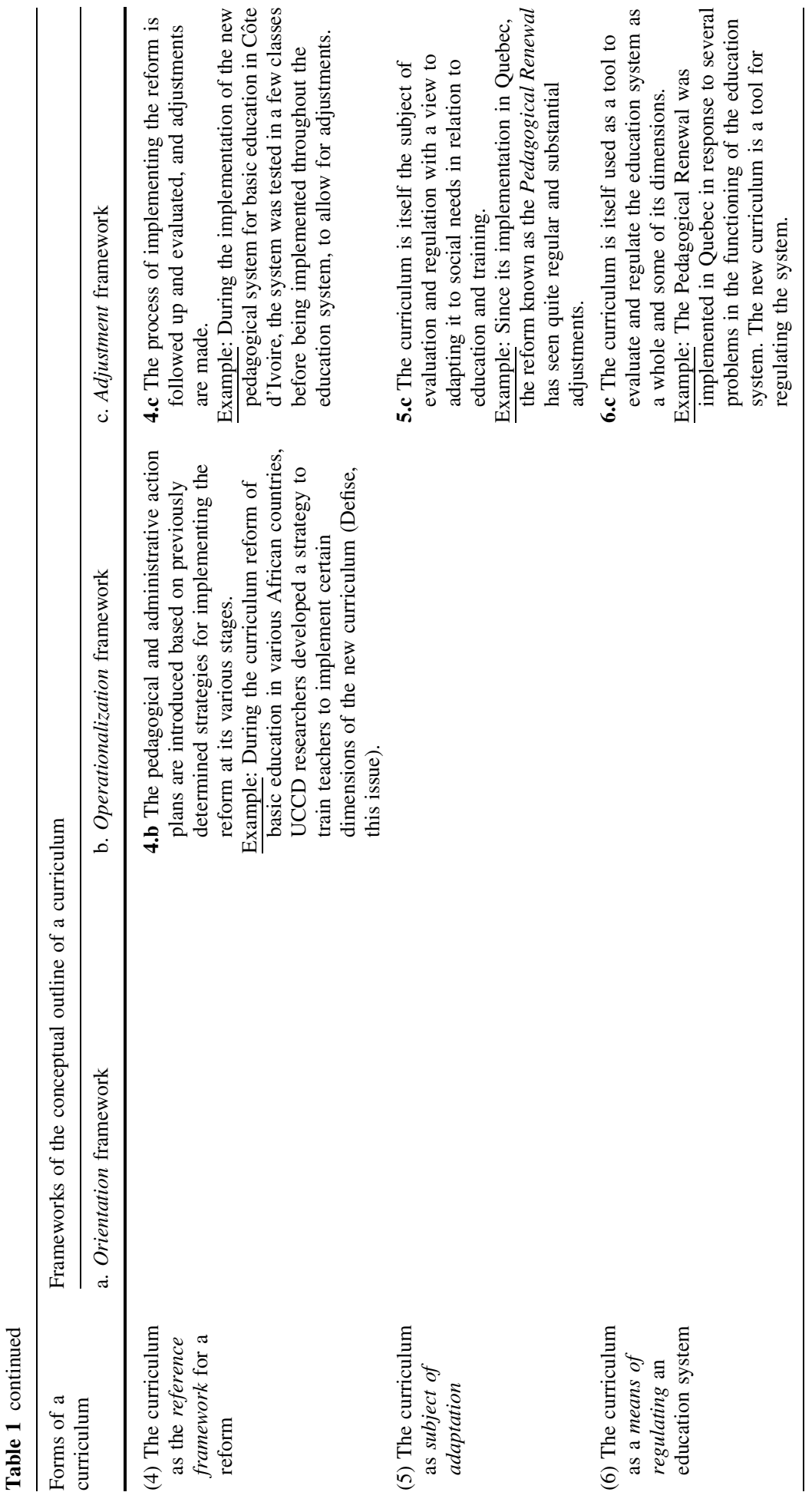


analysed, situates it in the strict context of its application. These various forms are also the translation of the very extended temporal scale over which a curriculum evolves, ranging from the first theoretical reflections through to its own adjustment. This is a plan that covers many years, often more than a decade.

For example, 2010 was the first time that the tests of the Pan-Canadian Assessment Program (PCAP) assessed the achievements and competencies of a cohort of about 30,000 13-year-old students who, in certain Canadian provinces such as Quebec, had had all of their basic schooling under a reformed curriculum. The PCAP, conducted every three years, tests Canadian students in mathematics, reading and writing, and science; Furtuna, in this issue, describes it in more detail. The first efforts on the reform, known in Quebec as the Pedagogical Renewal, started officially in 1994 with the États généraux for education. This was 16 years before the 2010 PCAP assessment, which targeted a cohort of students who had received all of their basic schooling under the new pedagogical system. Thus, we see that the development of a curriculum necessarily spans a long time period.

It is important to specify the stage of its evolution a curriculum is in when it is analysed, along with its form at that time and the box in the outline where it is situated. Only then can we envision the appropriate questions, like Tyler's. Research described in the Tehio (2010) volume shows that, in some countries, evaluations of curriculum reforms have been undertaken even before they were thoroughly implemented. This kind of continual movement of a curriculum, progressively adapted to the multiple emerging realities of an education system, can give teachers the impression that reforms follow each other rapidly, but in fact what is happening is a long process of implementing and adapting the same curriculum. Thus, it is crucial that teachers be involved throughout the curriculum process; in fact they should be trained in curriculum development, as is done, for example, in Finland (Halinen 2011).

The role of teachers evolves if there is agreement on this all-encompassing vision of the curriculum and of education: they are the co-developers of curricula, lifelong learners in relation to the evolving curriculum and dynamic agents of change. However, teachers often fear the reforms that are implemented in their country and the changes they involve... (Opertti and Duncombe 2011, p. 105)

Table 1 presents the cross-referencing between the formats of a curriculum and the three essential boxes of the general conceptual outline of a curriculum. Each cell corresponds to a particular stage in the time-scale of the development of a curriculum.

Traditionally, a curriculum will evolve through three phases: the intended curriculum, the curriculum that is implemented in the classroom, and the achieved curriculum: the level of coherence between students' learning outcomes and the orientations and prescribed content of the curriculum (Keeves 1992). The curriculum develops in a spiral motion through these phases. A complete model of a curriculum situates these three phases in relation to the various forms of the curriculum described above.

Each of the boxes in Table 2 relating to phases A and B can also be placed into Table 1. Curriculum development therefore relates essentially to boxes A.a to B.f in Table 2 (highlighted in grey). However, phase $\mathrm{C}$ is not found in Table 1. It relates to learning outcomes, and therefore to the curriculum implemented in the school system.

Each of the boxes in Table 2 also corresponds to a specific moment in the development of a phase of the same curriculum which, depending on the moment, takes on a specific form. This curriculum development process is not linear; it consists of multiple interactions between the boxes.

Current curriculum research, as well as development research in the field, tends to show how relative the hierarchy is between these boxes, focusing on phases versus forms 


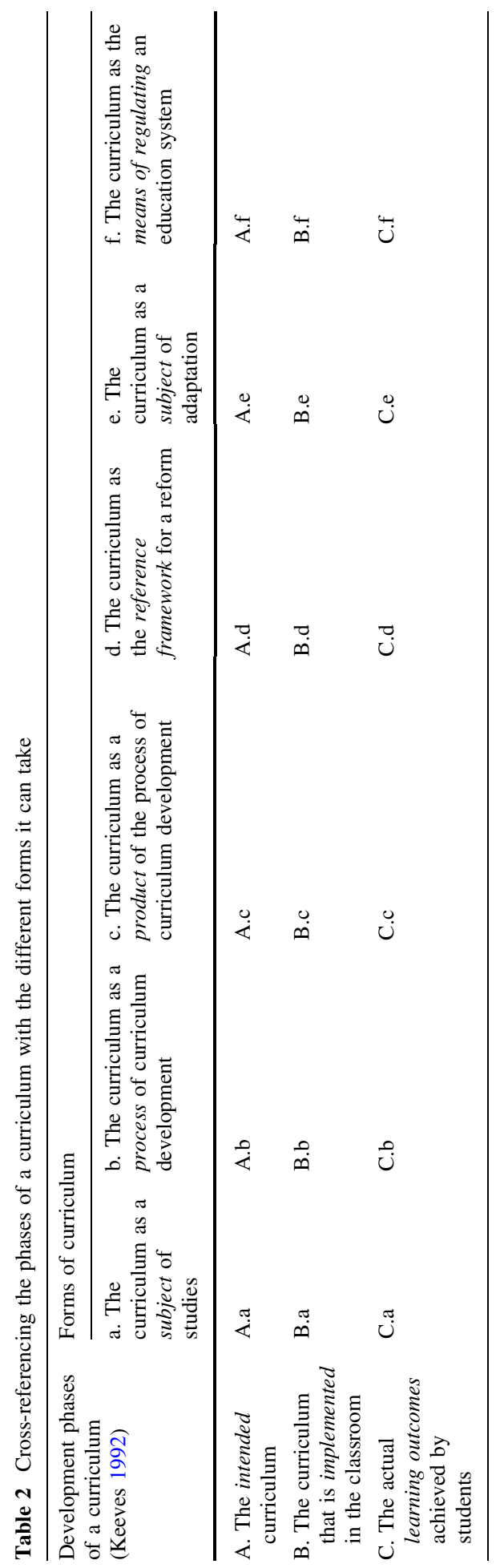


(Jonnaert 2011a). The everyday reality in education systems and their curricula can often be quite far removed from the abundant current debates, theories, and research on curricula, such as that reported in the European Educational Research Journal, International Review of Educational Reform, Journal of Curriculum Studies, Learning and Instruction, and Prospects, Quarterly Review of Comparative Education. Researchers have described many transformations and reconstructions between the three phases of the curriculum (Jonnaert 2011a, 2012; Keeves 1992): "evidently a goodly dose of naivety is required to suppose that the transition from one level to another can happen without alteration or transformation. No education researchers are now guilty of such innocence" (Crahay et al. 2006, p. 17).

These three phases of the curriculum, in their various forms, involve different actors and places that are only very episodically connected. A student in a classroom rarely has much knowledge of the whole structure of the education system, of which she/he is nevertheless the principal actor and for whom this unwieldy mechanism has been built up over time. In many international studies, however, the learning outcomes of students have also become indicators of how the education systems are actually functioning; this risky practice is now broadly denounced (Maroy and Mangez 2008).

The model we propose, which seeks to establish pointers for a debate on the concept of the curriculum, illustrates the rationality of a system based on phases with a logical and chronological succession. Although it is indeed the same curriculum that progresses from one phase to another, it nevertheless takes on different forms from one box to another in the two tables. These three phases of the same curriculum are then subject to a series of interpretations, transformations, deconstructions, and reconstructions, depending on the educational actors involved at this level, including political decision-makers and even students in classrooms.

Each of the 18 boxes in Table 1, cross-referenced with the three phases outlined by Keeves, provides a basis for developing categories of criteria for curriculum analysis. Our research team at UCCD is undertaking more research on this topic (CUDC 2013). Based on these categories of criteria, the pointers proposed by Tyler (1949) can be broadened to provide more complete analytical tools for researchers and curriculum developers.

However, would it be useful to go beyond Tyler's questions? Is it necessary to enclose a curriculum in a model that is quite rational and perhaps rigid, however dynamic it may be? In the following section, by way of conclusion, we question the rationality of a model for curriculum analysis. This section is adapted from Jonnaert (2011a).

\section{Irrationality of a curriculum and compromises}

Beyond the question of developing a model for the curriculum, we aim here to demonstrate that doing so is not entirely rational, and may even contradict everything that has gone before. If we specify orientations in a curriculum and translate them into programmes of studies, is that sufficient for everything to progress automatically from one curriculum level to another? Is it enough to develop analytical tools that help us understand the complexity of a whole curriculum? Are the pointers that have gradually been developed effective?

This line of thinking raises a series of questions that challenge the automatic and linear, and almost direct, transition from the intended curriculum to the attainments of students. How does an official curriculum progress through the various strata of an education system to enter the classroom, and to ensure that students really construct knowledge and develop 
competencies effectively in relation to the prescribed content of the curriculum and the knowledge codified in programmes of studies? How can this codified knowledge actually become the subject matter that students learn? Does any real feedback occur between the implemented curriculum and the intended curriculum?

Such questions show how fragile a curriculum is when presented as a logical and rational structure. A curriculum is more of a dynamic entity, constantly evolving and being transformed from one box to another in Tables 1 and 2, in a constant process of toing and froing. A close analysis should show this dynamic nature of a curriculum. It would also bring out its hesitations, contradictions, and incoherencies. The complexity of these movements goes beyond the logical framework of a curriculum and any form of strictly linear transposition. To understand a curriculum, researchers place it in its social and cultural environment, with the implications that emerge in any given society. As Claude Lévi-Strauss (cited in Enthoven and Burguière 2009) put it,

My profession as an ethnologist, the direct or indirect study of societies that are very different from our own and which differ between themselves, has led me to an understanding that no real or even possible society can ever accede to rational transparency. A society is not made on the basis of a system. Any society is primarily made of its past, its customs, its usages: a series of irrational factors against which theoretical ideas, that claim to be rational, flounder...

Because it belongs to a specific society, every curriculum must confront this irrationality. This partially explains the difficulty of analysing curricula over and above all rationalism. Still, these rational systems are necessary, although they are insufficient for curriculum analysis. Any curriculum is placed in a paradox like this: defined by rational systems, it operates in the irrationality of a particular society. A relatively significant proportion of the curricula analysed will always have shady areas that are difficult for researchers to access.

Rather than being presented in accordance with a hierarchical and linear model, the various levels of a curriculum should be in constant interaction with each other. Intersections should exist between these levels, which should be more or less significant depending on the education system and the type of curriculum that developed (Schiro 2008). However, these interactions and intersections are frequently affected by multiple forms of interference, making the system fairly irrational, and ultimately not that systemic in itself. For example, feedback from the achieved curriculum to the intended curriculum often occurs through parallel channels, such as teachers' unions or other pressure groups seeking some change or other in the education system. Only very rarely does the implemented curriculum respond to the opinions expressed by students. It tends to be their parents who take up the issue, either to contest a school report or to challenge the disappearance of the weekly dictation from their children's timetable. Major international surveys make use of their comments on student attainment to transmit information related to the intended curriculum, without the students themselves even being aware this is happening. The rationality of a curriculum is constantly perturbed by the opinions expressed by various actors, including the school partners and civil society. The latter never hesitate to question and challenge a curriculum and its evolution, even though they do not understand what it is based on. The rationality of this model remains relative and feedback from one level to another is rare and difficult.

A curriculum necessarily lies at the heart of the tensions that develop between a logical and rational model and the irrationality of the societies that govern it. These are the tensions which, in the end, impose compromises upon curricula that sometimes transform them into epistemological instances of trompe l'oeil (Jonnaert 2001). Through the curricula 
we analyse, members of our research team generally observe a trend or an ideology (Schiro 2008) that is dominant over all the other orientations and comes to include the other trends. "For example, many curricula are strongly focused on the knowledge to be acquired by school children and students but, nevertheless, neglect learners and the needs of society. In general, curricula are 'hybrids' of these trends, with a 'major orientation' that gives the tone to all the propositions in the curriculum" (Jonnaert et al. 2009, pp. 33-34).

A curriculum is generally built around a series of compromises imposed upon it by the society that governs it, and through which it guides the education system. These compromises are the source of contradictions that undermine the rigidity of a rational model. Are such tensions and compromises inevitable? Perhaps not, if we take a more holistic perspective, as we suggest now.

A curriculum that is considered to be anchored in the realities of a society distances itself from a technocratic vision, embedded in a rational curricular system and focused exclusively on the delivery of knowledge. A holistic perspective focuses fundamentally on learners, on their integration into their community, and on their openness to the world. In fact, these learners, who strangely have been forgotten in so much curriculum-related work, should be at the centre of concerns in this field of study. A holistic perspective considers everything that occurs at school, to optimize students' integration into their environment and the contemporary world. As Halinen (2011, p. 85) puts it, "The conception of the curriculum is holistic. Core national curricula, in the same way as local curricula, cover the whole of what happens in school, and not only the objectives and contents of the various subjects". Note that in Finland, the core curricula provide the basis (administrative, legal, intellectual, and pedagogical) upon which local curricula, adapted to the local realities of a school or area, are developed for various types of training. See Kartovaara (2007) and Halinen (2006, 2011) for more on Finnish curricula.

This holistic approach stands in some contrast to the rather irrational attitudes of multidimensional societies. From the outset, a holistic curriculum finds itself at the heart of these tensions as it integrates all the partners in the education system as it develops through veritable social dialogue (Jonnaert 2011b). Such an approach places the curriculum at the heart of tensions of varying strengths between the rational and the irrational, between the exogenous and the endogenous, between the local and the universal, between the contextualized and the decontextualized, between the intrinsic and the extrinsic, etc. But these are the tensions that first construct it and then characterize it, and which finally destabilize it and give rise to its reconstruction so that it can be adapted to the dynamic context in which it is developed. The questions we have referred to in this article are never complete and are constantly under construction; their very flexibility allows the curriculum to become both a tool of social dialogue (Jonnaert 2011b) and a means of adapting education systems to dynamic societies. Therefore, in the final analysis, the curriculum enables individuals to adapt to the society that is awaiting their development so that, through them, it can blossom into a society that is open to difference and to its own irrationality.

All of the articles in this thematic issue start out from a holistic vision of the concept of the curriculum: the curriculum understood as a global and inclusive system. Taken in isolation, each article may only present a partial dimension of a curriculum, and therefore lose any meaning. Therefore, we believe it is important to situate each article in the global context of the curriculum in which it is embedded. However, it is clearly difficult to describe in the introduction to each article the form of the curriculum to which it refers. In contrast, when taken out of this context, these articles are disconnected from the other dimensions of the curriculum with which they necessarily interact, and thus lose some of their meaning. It is in the multiple interactions between the components of a curriculum 
that we find the meaning of a particular observation. Each of the articles is not only perfectly placed in relation to the questions raised by Tyler (1949), but also to curricular phases and formats. Each of these articles provides a concrete illustration of at least one of the questions we have outlined here.

Why, in this thematic issue, do Geneviève Therriault and Léon Harvey analyse the ways that the epistemological posture of future teachers can change? Undoubtedly because the new curriculum requires that all involved gradually make the transition to an epistemological vision unlike the one that prevailed before the reform of their curriculum to train secondary teachers in Quebec.

Why does Rosette Defise examine the implementation of a reform of basic education in Benin in a study on the development of learning communities with teacher trainers? Undoubtedly because the new curriculum for basic education in Benin prescribes a new approach to the dynamic of classes in the country.

Why do Patrick Charland and Stéphane Cyr take a situated perspective as they reexamine education programmes in mathematics for basic education in Niger? Undoubtedly because, when they analysed the framework for curriculum orientation for basic education in that country, they observed that the curriculum prescribes the development of competencies by learners. Moreover, the curriculum calls for these competencies to be developed in situations that are meaningful for the learners.

Why has Daniela Furtuna defined a methodology for developing item banks with a view to identifying the competencies of students in West Africa to handle situations in mathematics and reading? Undoubtedly because the current standardized assessment tests for student attainments no longer correspond to the prescribed content of curricula for basic education in these countries, which orient training towards the development of competencies.

Outside these curricular contexts, the individual studies are of less interest. It is clearly through the curriculum in each of these four situations that their full significance can be developed. The challenge of this thematic issue lies in presenting these curricular tensions between the specific and the global. A curriculum is a system with multiple entry points. But we needed to demonstrate this. Starting out from a very global presentation of the curriculum and showing it in its full complexity, we have also described how the same curriculum can take on different appearances, by assuming very different forms during the successive phases of its development. The risk in a curriculum study is to fix a curriculum in the image that it offers of itself at a particular moment in its development. This is demonstrated by Roger-François Gauthier, who describes the difficulties encountered by the different education systems in the countries of West Africa. Is it possible to envisage a curriculum reform for basic education that addresses only one of these dimensions, such as how to organize the content of education programmes following a specific approach? One observation Gauthier made in relation to these West African reforms is the absence of a holistic vision, which would have made it possible to set these new approaches into a global curriculum system. Similarly, without denying that relevant education encourages students to develop competencies, Jean-Philippe Ayotte-Beaudet nevertheless demonstrates its fragility. He observes the weakness of the definitions, though the concept of competence is considered to be the main element tying certain curricula together.

Through their analyses in the various articles in this issue, the authors reveal the full complexity of curricular studies. Without enclosing a curriculum in a single model, the authors are today choosing a holistic framework: a systemic and global framework to address curricular issues. The curriculum therefore takes its place at the heart of the various 
tensions as it integrates all the partners in the education system as it develops through honest social dialogue. This is the framework within which innovative curricular models can be developed to respond to the urgent needs of dynamic education systems. We end with a quote from Nieto, Bode, Kang, and Raible (2008) that sums up our beliefs:

The field of curriculum studies has been critiqued ... for being an elitist intellectual pursuit that is out of touch with the realities of schools. At the other extreme, the curriculum that is implemented in actual schools is sometimes condemned as little more than a collection of textbooks and teachers' guides... We view curriculum as including not only texts, but also other instructional materials, programs, projects, physical environments for learning, interactions among teachers and students, and all the intended and unintended messages about expectations, hopes and dreams that students, their communities, and schools have about student learning and the very purpose of schools. (p. 179)

\section{References}

Audigier, F., Tutiaux-Guillon, N., \& Haeberli, P. (Eds.) (2008). Compétences et contenus. Les curriculums en questions [Competencies and contents: Curricula through questions]. Brussels: De Boeck.

Bobbitt, J. F. (1918). Curriculum. Boston: Houghton-Mifflin.

Bobbitt, J. F. (1924). How to make a curriculum. Boston: Houghton-Mifflin.

Braslavsky, C. (2001). Tendances mondiales et développement des curricula [Global trends and curriculum development]. Lecture given at the Journées internationales sur les politiques nationales d'éducation et de formation. Brussels: Association francophone d'éducation comparée (AFEC).

Chevallard, Y. (1985). La transposition didactique: du savoir savant au savoir enseigné [Pedagogical transition: From intellectual knowledge to taught knowledge]. Grenoble: La Pensée Sauvage.

Chevallard, Y., \& Joshua, M.-A. (1982). Un exemple d'analyse de la transposition didactique: la notion de distance [An example of the analysis of pedagogical transposition: The notion of distance]. Recherches en Didactique des Mathématiques, 3(2), 159-239.

Connelly, F. M., He, M. F., \& Fillion, J. (Eds.) (2008). The Sage handbook of curriculum and instruction. London: Sage Publications.

Connelly, F. M., \& Xu, S. (2008). The landscape of curriculum and instruction: Diversity and instruction. In F. M. Connelly, M. F. He, \& J. Fillion (Eds.), The Sage handbook of curriculum and instruction (pp. 514-533). London: Sage Publications.

Crahay, M., Audigier, F., \& Dolz, J. (2006). Introduction. En quoi les curriculums peuvent-ils être objets d'investigation scientifique? [Introduction: In what way can curricula be the subject of scientific investigation?]. In F. Audigier, M. Crahay, \& J. Dolz (Eds.), Curriculum, enseignement et pilotage (pp. 7-37). Brussels: De Boeck.

CUDC [Chaire UNESCO en développement curriculaire/UNESCO Chair in Curriculum Development] (2013). Organizational website. http://cudc.uqam.ca/.

D’Hainaut, L. (1970). Un modèle pour la détermination et la sélection des objectifs pédagogiques du domaine cognitif [A model for the determination and selection of pedagogical objectives in the cognitive domain]. Enseignement programmé, 11, 21-38.

D'Hainaut, L. (1971). L'enseignement des concepts scientifiques et techniques à l'aide de cours programmés [The teaching of scientific and technical concepts through programmed courses]. Doctoral thesis. Université Libre de Bruxelles (ULB).

D’Hainaut, L. (1981). Analyse et régulation des systèmes éducatifs, un cadre conceptuel [Analysis and regulation of education systems: A conceptual framework]. Brussels: Labor.

D'Hainaut, L. (1988). Des fins aux objectifs de l'éducation. Un cadre conceptuel et une méthode générale pour établir les résultats attendus d'une formation [From the purposes to the objectives of education: A conceptual framework and a general method for determining the expected outcomes of education]. Brussels: Labor.

Danvers, F. (1992). 700 mots-clés pour l'éducation [700 key words for education]. Lille: Presses Universitaires de Lille. 
Depover, C., \& Noël, B. (2005). Le curriculum et ses logiques. Une approche contextualisée pour analyser les réformes et les politiques éducatives [The curriculum and its logics: A contextualized approach for the analysis of educational reforms and policies]. Paris: L'Harmattan.

Dewey, J. (1899). The school and society. Chicago: University of Chicago Press.

Dewey, J. (1902). The child and the curriculum. Chicago: University of Chicago Press.

Dewey, J. (1938). Experience and education. New York: Collier Books.

Enthoven, J.-P., \& Burguière, A. (2009). Un artisan, pas un maître penseur. Ce que je suis [An artisan, not a master thinker: What I am], by Claude Lévi-Strauss. 1980 interview in the Nouvel Observateur. Nouvel Observateur Hors-Série, 31, 30-36.

Forquin, J.-C. (1984). La sociologie du curriculum en Grande-Bretagne: une nouvelle approche des enjeux sociaux de la scolarisation [The sociology of the curriculum in Great Britain: A new approach to the social issues of schooling]. Revue française de sociologie, 25(2).

Forquin, J.-C. (1989). École et culture. Le point de vue des sociologues britanniques [School and culture: The viewpoint of British sociologists]. Brussels: De Boeck.

Forquin, J.-C. (2008). Sociologie du curriculum [Sociology of the curriculum]. Rennes: Presses Universitaires de Rennes.

Gauthier, R.-F. (2011). Une autre façon de penser l'éducation [Another way of considering education]. Revue Internationale d'Éducation de Sèvres, 56, 31-40.

Halinen, I. (2006). The Finnish curriculum process. In A. Crisan (Ed.), Current and future challenges in curriculum development: Policies, practices and networking for change (pp. 62-78). Bucharest: Humanitas Educational.

Halinen, I. (2011). Le curriculum en Finlande: un outil puissant au service de l'éducation [The Finnish curriculum: A powerful tool in service to education]. Revue Internationale d'Éducation de Sèvres, 56, 77-88.

Jackson, P. W. (1992). Conception of curriculum and curriculum specialists. In P. W. Jackson (Ed.), Handbook of research on curriculum: A project of the American Educational Research Association (pp. 3-40). New York: Macmillan.

Jonnaert, P. (2001). La thèse socioconstructiviste dans les nouveaux programmes d'études au Québec: un trompe l'œil épistémologique? [The socio-constructivist approach in the new programmes of studies in Quebec: An epistemological trompe l'oeil?]. Canadian Journal of Science, Mathematics and Technology Education, 1(2), 223-230.

Jonnaert, P. (2011a). Curriculum, entre modèle rationnel et irrationalité des sociétés [Curriculum: Between a rational model and the irrationality of societies]. Revue Internationale d'Éducation de Sèvres, 56, 135-145.

Jonnaert, P. (2011b). Des programmes d'études endogènes articulés aux standards internationaux en République du Niger [Endogenous programmes of studies articulated using international standards in the Republic of Niger]. ACDI-CIDA [Canadian International Development Agency]. Education Newsletter, 3, 4-5.

Jonnaert, P. (2012). Postface. In P. Charland, C. Daviau, A. Simbagoye, \& C. Stéphane (Eds.), Écoles en mouvements et réformes. Enjeux, défis et perspectives (pp. 221-232). Brussels: De Boeck.

Jonnaert, P., \& Ettayebi, M. (2007). Le curriculum en développement. Un processus dynamique et complexe [Curriculum development: A dynamic and complex process]. In L. Lafortune, M. Ettayebi, \& P. Jonnaert (Eds.), Observer les réformes en éducation (pp. 15-32). Québec: Presses de l'Université du Québec.

Jonnaert, P., Ettayebi, M., \& Defise, R. (2009). Curriculum et compétences. Un cadre opérationnel [Curriculum and competencies: An operational framework]. Brussels: De Boeck.

Kartovaara, E. (Ed.) (2007). Perusopetuksen vuoden 2004 opetussuunnitelmauudistus [Reform of the 2004 core curriculum for basic education]. Helsinski: Opetushallitus.

Keeves, J. (1992). Methodology and measurement in international and educational surveys. London: Pergamon Press.

Kliebard, H. M. (1995). The struggle of the American curriculum, 1893-1958. New York: Routledge Falmer.

Kridel, C. (Ed.) (2009). Encyclopedia of curriculum studies. London: Sage Publications.

Lafortune, L., Ettayebi, M., \& Jonnaert, P. (Eds.) (2007). Observer les réformes en éducation [Observing education reforms]. Quebec: Presses de l'Université du Québec.

Laveault, D. (2007). Quelles compétences, quels types de validité pour l'évaluation [What competencies, what types of validity for assessment?]. In L. Bélair, D. Laveault, \& C. Lebel (Eds.), Les compétences professionnelles en enseignement et leur évaluation (pp. 27-50). Ottawa: Presses de l'Université d'Ottawa.

Le Moigne, J.-L. (1987). Systémographie de l'entreprise [Enterprise systemography]. Revue Internationale de Systémique, 1(4), 499-531. 
Luke, A. (2008). Curriculum in context. In F. M. Connelly, M. F. He, \& J. Fillion (Eds.), The Sage handbook of curriculum and instruction (pp. 145-150). London: Sage Publications.

Malet, R. (Ed.) (2010). Écoles, médiations et réformes curriculaires. Perspectives internationales [Schools, mediation, and curriculum reform: International perspectives]. Brussels: De Boeck.

Maroy, C., \& Mangez, C. (2008). Rationalisation de l'action publique ou politisation de la connaissance? [Rationalization of public action or politicization of knowledge?]. Revue française de pédagogie, 164, 87-90. http://www.rfp.revues.org/2136.

Martinand, J.-L. (1986). Connaître et transformer la matière: des objectifs pour l'initiation aux sciences et techniques [Knowing and transforming the subject: Objectives for an initiation to sciences and techniques]. Bern: Peter Lang.

Martinand, J.-L. (2001). Pratiques de référence et problématique de la référence curriculaire [Reference practices and problems with the reference curriculum]. In A. Terrisse (Ed.), Didactique des disciplines, les références au savoir (pp. 17-24). Brussels: De Boeck.

Nieto, S., Bode, P., Kang, E., \& Raible, J. (2008). Identity, community and diversity: Retheorizing multicultural curriculum for the postmodern era. In F. M. Connelly, M. F. He, \& J. Phillion (Eds.), The Sage handbook of curriculum and instruction (pp. 179-197). London: Sage Publications.

Opertti, R., \& Duncombe, L. (2011). Vision curriculaire. Perspective d'ensemble et débats contemporains [Curriculum vision: Overview and contemporary debates]. Revue Internationale d'Éducation de Sèvres, 56, 101-110.

Perrenoud, P. (1984). La fabrication de l'excellence scolaire [The creation of school excellence]. Geneva: Droz. Pinar, W. F. (2003). International handbook of curriculum research. Mahwah, NJ: Lawrence Erlbaum.

Pinar, W. F. (2004). What is curriculum theory?. Mahwah, NJ: Lawrence Erlbaum.

Pinar, W. F. (2009). Curriculum theory. In C. Kridel (Ed.), Encyclopedia of curriculum studies (pp. 267-270). London: Sage Publications.

Reuter, Y., Cohen-Azria, C., Daunay, B., Delcambre, I., \& Lahanier-Reuter, D. (Eds.) (2007). Dictionnaire des concepts fondamentaux des didactiques [Dictionary of the fundamental concepts of teaching]. Brussels: De Boeck.

Schiro, M. S. (2008). Curriculum theory: Conflicting visions and enduring concerns. London: Sage Publications.

Tehio, V. (Ed.) (2010). Politiques publiques en éducation, l'exemple des réformes curriculaires. Étude sur les réformes curriculaires par l'approche par compétences en Afrique [Public education policies-the example of curriculum reform: Study of curriculum reform adopting the competency-based approach in Africa]. Sèvres: Centre International d'Études Pédagogiques (CIEP).

Tyler, R. W. (1949). Basic principles of curriculum and instruction. Chicago: University of Chicago Press. UIS [UNESCO Institute of Statistics] (2012). International standard classification of education (ISCED). http://www.uis.unesco.org/Education/Pages/international-standard-classification-of-education.aspx.

Verret, M. (1975). Le temps des études [The time for studying]. Lille: Atelier de reproduction des thèses.

Wraga, W. G., \& Hlebowitsh, P. S. (2003). Toward a renaissance in curriculum theory and development in the USA. Journal of Curriculum Studies, 35(4), 425-437.

\section{Author Biographies}

Philippe Jonnaert (Belgium, Canada) is a professor at the Université du Québec à Montréal (UQAM) in Canada, and titular member of the UNESCO Chair in Curriculum Development (UCCD). Working with UCCD teams, he has developed varied strategies to support ministries of education, particularly in subSaharan Africa, in their efforts to optimize their education systems. A member of the Canadian Commission for UNESCO, he also consults for the major international organizations. His work focuses on curriculum engineering, development, and regulation processes. He has written many books and articles, which have been translated into several languages.

Geneviève Therriault (Canada) holds a Ph.D. in education from the Université du Québec à Rimouski (UQAR). Since 2009, she is a professor at the UQAR, where she directs the master and doctoral education programme. She was a post-doctoral scholar at the Research Centre on Academic Success (CRIRES), at the Université Laval in Quebec. She is affiliated with CRIRES, the Research Group on Learning and Socialization (APPSO), and the Research Centre on Environmental Education and Training and EcoCitizenship (Centr'ERE). Her interests include epistemology and the issue of the individual's relationship with knowledge in teacher training and in training in general. She has worked as a secondary school teacher, lecturer and author of teaching guides. 